\title{
PROBLEMS OF RUSSIAN ECONOMIC SUSTAINABILITY IN CONDITIONS OF DEBT ECONOMY
}

\author{
V.V. Moiseev \\ Shukhov Belgorod State Technological \\ University, 46 Kostyukova St., Belgorod, 308012, Russia \\ din_prof@mail.ru \\ Zh.N. Avilova \\ Belgorod State University, Russia, 308015, Belgorod, \\ Pobedu str, 85 \\ janna-avilova@mail.ru
}

\author{
V.F. Nitsevich \\ State University of Management, Moscow, Ryazanskiy \\ prospect, 99. 109542, Russia \\ dr.nitsevich@mail.ru \\ O. A. Sudorgin \\ State University of Management, Moscow, Ryazanskiy \\ prospect, 99, 109542, Russia \\ sudorginoleg@yandex.ru
}

\begin{abstract}
Focusing on the specific causes of the economic crisis in the $\mathrm{EU}$, the authors note that the most important of them is the domination of unreasonably high social standards over the economic opportunities for their support. According to the authors, it is the debt nature of the European economy that frees European governments from the need to carefully balance the growth of public spending with revenues and creates an imaginary sense of economic well-being, which ultimately leads to profound economic shocks.
\end{abstract}

Considering the problems hindering the sustainable economic development of Russia, the authors are looking for ways to overcome them. According to the authors, sustainable economic development of the Russian economy will be facilitated by the following factors: optimizing Russia's participation in the world economy with an orientation towards a policy of economic independence; priority of stimulating economic development over financial stabilization; correcting the imbalances in the structure of the economy in favor of the real sector; implementation of large-scale state-building projects involving private capital; introduction of modern management methods; orientation on the digital economy and optimal development of labor resources.

The authors believe that the key to successful sustainable economic development is a qualitative change in human capital.

Keywords - model of debt economy, paternalism, economic crisis, modernization, economic growth.

\section{INTRODUCTION}

The world economy is experiencing difficult times today. A clump of accumulated problems and contradictions is an indisputable fact nowadays. These problems and contradictions, in our opinion, are laid in the very basis of the modern economic system. Both the debt nature of the modern world economy and as a result the disproportions in the financial sector hamper the sustainable development of the world economy as a whole. The dominance of the syndrome of paternalism and social dependency in the European Union aggravates the economic instability of the European economy.

The predominance in Russia's economic policy of the principles of financial stabilization over stimulating economic development slows down the transformation of the structure of the Russian economy and its departure from the commodity orientation, it also aggravates regional and social disproportions and slows down the development of productive forces.

\section{PROBLEM STATEMENT}

The vulnerability and volatility of modern economy and economic policy are largely due to their debt nature. Since the second half of the XX century, the world has changed radically, an entirely new economic model has appeared - a new "economic universe". Until the middle of the last century, the vast majority of people, businesses and governments had been living in accordance with the principle of "spending not more than one has". "Life on credit" was not at all typical, credits and loans were considered as a temporary phenomenon. Rationally thinking governments sought to balance the budget, i.e. oriented on the fact that one cannot spend more money than collected in the state treasury. But from the second half of the 20th century (and this has become especially clear since the 1980s), the gradually unshakable norms of the rationality of economic behavior have ceased not only to act but also to be recognized as norms. Before that, firms and banks issued securities in order to attract free capital to real production. Today, the issue of securities has completely different purposes. Modern securities are provided not by real assets but by the value of previously issued securities. The financial sector provides systematic growth of quotations of securities by means of hidden manipulation of their value, specific methods of asset valuation, exchange games, etc. In fact, the more isolated from real assets a 
security is, the easier it is to raise its quotations. In such conditions, deposits in banks and especially investments in real production bring investors much less profit and cannot stand competition for savings of households and firms. Being attracted by the rapid growth of quotations of securities, households and firms invest their savings in them, allowing financial structures to pay high interest, thus attracting more and more new entrants. Essentially, a mechanism has been created for the redistribution of financial assets in favor of the stock market and the value of securities is growing at a pace that is much faster than production growth. This system generates a corresponding psychology among consumers, managers of firms, bankers and, as a consequence, the tendency of mass investment of financial assets in the stock market. At the same time, there is a false sense of financial solvency, pushing the growth of consumption. This was clearly shown by the crisis of 2008.Consumer spending, at the same time, is financed not at the expense of disposable income but at the expense of loans, while the money earned is invested in securities. Companies receive loans on the security of their shares the value of which is growing rapidly. Homeowners and citizens, being owners of securities, feel more and more wealthy due to the rise in prices for real estate and securities and are actively taking loans secured by their property. As a result, the model of "debt economy" is formed. Such a "debt economy" at the stage of economic recovery is beneficial to all - the government, banks, industry, hired workers. However, at the stage of recession, it is disastrous [2]. At the time of the financial crisis, securities are depreciating, all market participants - firms, banks, households, and states remain with their loans and debts whose value is much higher than the value of depreciated securities [1].

So, first of all, the modern economic system and, in particular, its financial sector, which emits securities and their derivatives, allows people to spend unearned money. And literally all participants in economic relations can do this beginning with consumer households and ending with governments [4, 14].

It should be noted that the psychology of economic waste has been formed in a gradual way. Once, the conservatism of economic thinking used to be a barrier that did not allow one to get into debt. But, as often happens, there are pioneers risky, enterprising people who successfully sell not goods and services but future incomes. The psychological barrier is overcome: it turns out that one can spend more than one has ever earned, earns now and will earn in future without any unpleasant consequences. Management of public finances in these conditions actually becomes similar to manipulation - on the one hand, by certain virtual quantities, and, on the other hand, by public consciousness. Traditional methods and instruments of public administration in the new economic system under conditions of globalization prove to be ineffective, they are simply not working. And such a situation suits everyone which is the most menacing and depressing fact. Nobody wants to seriously revise the situation. No one wants to go back and learn to live using only one's modest earnings again. Being accustomed to live on credit and to consuming not even future incomes but expectations of future incomes, having survived one destructive crisis and being perfectly aware of the imminence of subsequent ones households, firms, banks and governments, nevertheless, are already so corrupted by the system of debt economy that it would be out of the question for them to agree to reduce consumption and to commensurate with real incomes.

Unfortunately, not only consumers and entrepreneurs but also states in the form of governments turned out to be addicted to the debt economy. In recent years, economists have been tending to consider a situation as normal when the national debt amounts to $60 \%$ or $70 \%$ of GNP. The state repays the debt at the expense of tax revenues. The taxation limit, as a rule, is $15-25 \%$ of GNP and it would definitely be impossible to tax the economy to the extent of $100 \%$ of GNP, as it is impossible to spend all incomes on repayment of debts only.

The analysis of economic crises over the past 30 years suggests that under the disproportional development of the financial sector and globalization, irresponsible policies of governments of individual countries and international organizations will sooner or later lead to a civilization catastrophe [8].

One of the first precursors of this catastrophe is the situation in the EU. The economic crisis in Europe in general and in the EU countries in particular was developing as a part of the global crisis. But it should be noted that, in addition to some general reasons, the European crisis has got specific ones. The most important of them is the dominance of social policy over economic goals, unreasonably high social standards, and, as a consequence, the volume of social support for the population. The debt nature of the economy frees the governments of European countries from the need to carefully correlate the growth of public spending with incomes. As a result, governments are assuming ever greater and greater social obligations with costly commitments: free health care and secondary education, inexpensive higher education, high salaries in all fields, ensuring of a decent old age, supporting national culture and the environment etc [11].

The process of socialization in many European countries can be described as a gradual transfer of the function of supporting "dependents" from family to state, from a community of people connected by blood and marriage to a community of people dependent on civil servants. So, the social policy implemented in the XX century in Sweden and then in many other European countries was aimed at improving the quality of human capital and at the same time radically redistributing income. Never before has the state bureaucracy been endowed with such powers. Practically all families became objects of support, supervision and control. The so-called "preventive social policy" supports the following issues: a universal health insurance system, universal state benefits to cover the indirect costs associated with raising children (for children's clothing, free kindergarten visits, free meals for schoolchildren, state children's summer camps etc.). This includes state-funded housing construction for families, loans to newlyweds, expansion of public services in the field of obstetrics and gynecology, centralized economic planning etc. There happens a socialization of consumption in 
which the provision of a set of services is managed by civil servants, and financing is provided by taxing the rich and childless ones. As a result, instead of developing a "welfare society", we get a "society of dependents" where citizens are dependent on a large group of civil servants who patronize them throughout their lives. The desire to "help all" pushes governments to actions that are contrary to economic logic. For example, increase the volume of social transfers while not raising taxes and even lowering them. The processes of integration (primarily within the EU) lead to the fact that residents of not the most prosperous countries begin to live according to psychology and the social and economic standards of the rich ones.

It is gratifying that today everyone is recognizing the need for humanization of society and that the happiness of each individual is recognized as the highest goal of human development. Human rights, democracy and the rule of law are considered the fundamental basis of the European Union. In the European Union it is believed that the protection of the minority is important in itself, based on the principles of humanity and freedom. It was this policy that led to a catastrophic situation with refugees. According to the OECD, their number in 2015 had reached unprecedented levels. About one million applications for asylum had been received, approximately 350,000 to 450,000 people had been granted refugee status or an equivalent one. However, the distribution of refugees across countries is uneven. The most affected country was Turkey, where there were 1.9 million Syrians as well as a large number of refugees from Iraq. Within the EU, on the front line there are Italy, Greece and Hungary but the main destination countries are Germany as well as Sweden and Austria [21].

Refugee flows tend to be concentrated in countries with the most favorable living conditions. A developed labor market and a high level of social protection is the most important factor that determines the flows of the main refugee groups. Europe currently has better legal and institutional systems for migrants than it used to have in the 1990s. However, these systems haven't managed to ensure an equitable burden sharing between countries and did not prevent the unauthorized arrival of refugees.

Politicians are looking for ways out of the current crisis in the redistribution of refugee flows by means of optimizing financial flows aimed at supporting them. However, such measures are not able to solve the global problem and prevent imminent crises in the future.

The financial resources of a country are not unlimited and the problem of state regulation, connected with the lack of financial resources and the imbalance in their redistribution, is particularly clear when a country's economic system is characterized by a number of serious problems that need to be solved through modernization [6].

Much of the issues mentioned above largely apply to the Russian economy. In addition, the Russian economy is hampered by a number of problems that require immediate solution:
- An essential part (according to some estimates, more than $40 \%$ ) of production capacities in Russia is obsolete technologically and physically and cannot produce competitive and market-consumed products. The state does not have the necessary means to modernize the economy economically: according to the data of the Russian Ministry of Finance, the budget deficit in 2016 was $3.4 \%$ of GDP and in 2017 it amounted to $1.4 \%[15 ; 16]$. State companies do not have any free resources, and private and foreign companies are not ready to invest in Russia today because of the lack of confidence. The share of investments in fixed assets in the country's GDP had increased by $0.5 \%$ (from $20.7 \%$ to $21.2 \%$ ) during six years (from 2011 to 2017). The share of high-tech and knowledge-intensive industries in the country's GDP had increased by $2 \%$ over the same period (from $19.7 \%$ in 2011 to $21.7 \%$ in 2017) [19]

- In the field of energy and logistics efficiency Russia has lagged far behind the competitors in the rest of the world. The Russian economy requires 4 times more energy than Japan to produce 1 dollar of the GDP. And the cost of transportation, storage and customs clearance in Russia is much higher than in developing countries and even than in many developed countries. Thus, the competitiveness of manufactured goods is decreasing, and this is a barrier on the way to increasing production and sales markets [13].

- In the field of productive capacities Russia is increasingly suffering from a shortage of labor resources, they are reduced by $0.5 \%$ per year due to natural demographic reasons. At the same time, most of the labor force is involved in areas with zero or very low levels of value added: in the civil service, in security forces, private security, trade and extremely inefficient banking. The rest does not cover the needs of the country. Even with today's level of development of production and service there is a disastrous lack of engineering and technological personnel, highly-skilled workers and also efficient managers [13].

Table 1 presents data on the number of high-productivity jobs by types of economic activity in the Russian Federation for the period 2013-2016.

TABLE I. THE NUMBER OF HIGH-PRODUCTIVITY JOBS BY ECONOMIC ACTIVITY IN THE RUSSIAN FEDERATION (2013 - 2016), THOUSAND UNITS [19].

\begin{tabular}{|c|c|c|c|c|}
\hline & $\mathbf{2 0 1 3}$ & $\mathbf{2 0 1 4}$ & $\mathbf{2 0 1 5}$ & $\mathbf{2 0 1 6}$ \\
\hline Russian Federation, total & $\mathbf{1 7 4 9 2 , 8}$ & $\mathbf{1 8 2 8 0 , 9}$ & $\mathbf{1 6 7 8 2 , 4}$ & $\mathbf{1 5 9 8 3 , 3}$ \\
\hline including: & & & & \\
\hline $\begin{array}{c}\text { Agriculture, hunting, forestry } \\
\text { and fishing }\end{array}$ & 367,3 & 401,2 & 350,4 & 367,3 \\
\hline Extractive industry & 878,1 & 852,1 & 854,1 & 852,1 \\
\hline Manufacturing industry & 3670,8 & 3722,9 & 3333,9 & 3214,0 \\
\hline $\begin{array}{c}\text { Production and distribution of } \\
\text { electricity, gas, water }\end{array}$ & 910,1 & 998,6 & 926,8 & 891,5 \\
\hline Construction & 1046,3 & 1028,0 & 871,9 & 736,3 \\
\hline $\begin{array}{c}\text { Trade, repair of machinery, } \\
\text { household services }\end{array}$ & 1479,2 & 1609,4 & 1548,5 & 1535,0 \\
\hline Hotels and restaurants & 112,8 & 124,3 & 92,2 & 95,3 \\
\hline Transport and communications & 1632,9 & 2092,8 & 1787,7 & 1695,2 \\
\hline Financial activities & 1064,4 & 949,9 & 907,6 & 853,6 \\
\hline $\begin{array}{c}\text { State management, security, } \\
\text { social insurance }\end{array}$ & 2518,6 & 2458,9 & 2307,4 & 2178,4 \\
\hline Education & 721,6 & 782,0 & 786,9 & 643,7 \\
\hline
\end{tabular}




\begin{tabular}{|c|c|c|c|c|}
\hline Health and social services & 891,8 & 916,8 & 907,8 & 808,8 \\
\hline
\end{tabular}

\begin{tabular}{|l|l|l|l|l|}
\hline Other services & 2198,9 & 2344,3 & 2107,2 & 2112,1 \\
\hline
\end{tabular}

- Inconsistent and illogical policies in the field of lawmaking and law enforcement do not help increase the number of citizens who want to engage in entrepreneurial activities. According to Russian Public Opinion Research Center (VTsIOM) data for May 2016 65\% of the citizens surveyed considered business activity worthy and positive, one third of the respondents did not rule out the possibility to start their own business, only $17 \%$ took any steps for this and only $2 \%$ actually had their own business. These $2 \%$ included representatives of large businesses and also individual entrepreneurs [20].

According to the Federal Tax Service of Russia as of September 2017, 5.7 million small and medium-sized businesses (SMEs) operate in the Russian Federation, including 2.7 million legal entities and nearly 3 million individual entrepreneurs. In the SME sector, there are 5,409,226 microenterprises, 266148 small enterprises, and 20235 medium-sized enterprises that create jobs for 19 million citizens. In fact, every fourth employee is engaged in a SME. The contribution of the SME sector to the country's GDP is about $20 \%$. The SME sector in Russia is represented mainly by microenterprises ( $95 \%$ of the total number of SMEs) where on average one single worker is employed. The sectoral composition of the SME sector is mainly trade and services to the population [17].

- From $15 \%$ to $90 \%$ of Russian production (depending on the industry) is more or less tied to imports of raw materials, components or equipment [13]. In machinery construction, we can note extremely high dependence on imported raw materials, spare parts and components. Currently, the share of imported goods in the machine tool industry exceeds $90 \%$. In heavy engineering, the share of imported parts amounts to 60$80 \%$, in light industry - to $70-90 \%$, in electronics - to $80-$ $90 \%$, in pharmaceuticals and medical industries - to $70-80 \%$. By 2020, the dependence of the most critical industries on imports may fall from $90 \%$ to $50-60 \%$. The most promising fields for import substitution are machinery construction, light industry, heavy engineering, radio electronics, pharmaceuticals and the medical industry [18].

The dominance of the principles of financial stabilization in the economic policy of Russia over stimulating economic development leads to such consequences as: the official withdrawal of financial resources abroad (during the last 10 years $\$ 680.1$ billion was withdrawn or almost 3 state budgets of Russia[5]), the transformation of the structure of the Russian economy into one based on raw materials, the development of regional and social imbalances, the degradation of human capital, the reduction of social and living standards and the decline of demographic indicators.

To the important foreign policy factors negatively affecting the Russian economy, perhaps, only sanctions and counter-sanctions can be attributed. Their influence is greatly exaggerated, though [10]. In other respects, in our view, the foreign policy situation for Russian economic agents is quite favorable: Russia is a member of the WTO and other international economic organizations; its reserves are placed in the most liquid instruments and currencies; foreign exchange and foreign trade operations are conducted without restrictions; yields on sovereign debts are on low levels.

According to the UN regulation, the highest goal of public policy is to achieve sustainable development, understood as economic growth which has no fundamental negative environmental consequences and is sufficient to solve the main social problems. How applicable is this goal setting for Russia? Sustainability in itself cannot be a goal of economic development and policy. Sustainability should be understood not only as a guarantee of economic growth but also as the sustainability of the state system itself, including state borders, territorial integrity and sovereignty, it should be understood as social stability and as the creation of an environmental safety system. To achieve these goals, it is necessary to solve the following problems [6]:

1) To abandon the policy of dependence on external factors and to focus on the policy of economic independence, implying self-reliance, and also on national sources of economic growth and development. At the same time, we are talking about optimizing Russia's participation in the global economic system, rather than its refusal to open the economy.

2) To transfer from the policy of financial stabilization to the policy of stimulating economic development.

3)To correct (in favor of the real sector) the accumulated disproportions of the Russian economy, focusing on taking advantage of the digital economy.

4)To restore the proper level of state construction, corresponding to the priorities of the country's economic development.

5) To contribute to the development of productive capacities and to creation of new jobs and industries also to stimulate, through reasonable supply, domestic demand for local goods, increasing the purchasing power of the population.

\section{RESEARCH QUESTIONS}

1. Detection of a relationship between the volatility and vulnerability of the modern world economy and the debt nature of its development.

2. Identification of specific causes of the economic crisis in the EU.

3. Analysis of the problems that slow down the development of the Russian economy and the ways to solve them.

\section{PURPOSE OF THE STUDY}

The purpose of this study is to focus on the key issues hindering the sustainable development of the world economy as a whole as well as the economies of the European Union and Russia in particular. 


\section{Methods OF RESEARCH}

In the article the authors used the analytical, comparative, institutional and sociological methods as well as the method of system approach.

\section{FINDINGS}

Given there is disproportionality of the development of the financial sector and globalization, global and local economic crises will occur more and more often and it will be increasingly difficult to overcome them.

In order to successfully overcome all the growing economic crises, it is first of all necessary to recognize the viciousness of the existing system of reproduction and of the debt, virtual economy, parasitic on the real sector, on the one hand, and the false-social state, on the other. It is necessary to radically change the state policy by turning it to the needs of the real sector of the economy, tightening the regulation of the financial sector $[3 ; 12]$. It is necessary to redistribute financial flows in favor of the real and not the virtual sector of the economy. It is also required to reconsider the fundamental principles of state social policy and to overcome the syndrome of state paternalism and social dependency.

State management requires national medium- and longterm planning and forecasting -combined with effective economic rather than administrative tools to ensure the implementation of all these plans.

For a sustainable economic development, the Russian economy needs not just to carry out technical modernization, to install the most advanced equipment, to apply advanced technologies, to modernize enterprises, to introduce modern management methods and, for this purpose, to prepare a new generation of managers [7]. Weneedadequatetaskstochangethementalityofoursocietyaswell asitsmoral and ethical guidelines and social or cultural institutions. Unlike technical modernization, such a task cannot be solved in a short period of time even if the necessary financial resources are available. It takes much longer time. In this case, we are moving to a more global goal than just modernizing the economy - it is the aim to modernize the whole society.

\section{CONCLUSION}

It is important to understand that without modernization of society it is impossible to modernize the economy and change the model of its development. Otherwise, any transformation of the economy will be unstable and the system will sooner or later return to its original, pre-modernization form Therefore, one of the main tasks of sustainable economic development is introducing qualitative changes in human capital and its growth

\section{References}

[1] G.I. Arutyunova, I.V. Kirova, T.L. Popova, "On the nature of the current economic crisis". Bulletin of the Moscow State Automobile and Road Technical University (MADI), vol. 3, pp. 80-85, March 2009.
[2] G.I. Arutyunova, I.V. Kirova, T.L. Popova, "Lessons of the economic crisis", Bulletin of the Moscow State Automobile and Road Technical University (MADI), vol.2, pp. 56-60, February 2010.

[3] V.V. Beznovskaya, M.V. Kuntzman, M.S. Moskvina "On the question of national wealth", Automobile. Road. Infrastructure. vol.4 (6), pp 22-23, 2015.

[4] V.P. Vishnevsky, A.V. Matyushin, E.N. Vishnevskaya, "Monetary mechanism of the development of the EU economy", Economics of industry, vol. 2 (70). pp. 33-67, February 2015.

[5] E.V. Galkina, V.V. Moiseev, "State policy of knowledge-based economy: actual problems in Russia", International Journal of Pharmacy \& Technology, vol. 8 (4), pp. 24681-24692, 2017.

[6] I.V. Kirova, T.L. Popova, "State regulation and modernization" Bulletin of the Moscow State Automobile and Road Technical University (MADI), vol. 2, pp. 57-64, 2012.

[7] I.V. Kirova, T.L. Popova, Modernization of the economy: world experience and Russian perspectives, Bulletin of the Moscow State Automobile and Road Technical University (MADI), vol. 1, pp. 51-58, 2011.

[8] I.V. Kirova, T.L. Popova, "World economy and international economic relations". In 2 parts. Part 1 . Globalization: a course of lectures, M.: MADI, 68 p. , 2014

[9] I.V. Kirova, T.L. Popova, "Transformation of social relations as an element of the modernization of the Russian economy", Bulletin of the Moscow State Automobile and Road Technical University (MADI), vol. 1(36), pp. 65-73, 2014.

[10] I.V. Kirova, T.L. Popova, "Economic sanctions: history and modernity", Automobile. Road. Infrastructure, vol 3(5), pp.6-7, 2015

[11] I.V. Kirova, T.L. Popova, "The crisis of Europe as a quotient of a new economic model", Digest: the economics of modern society - actual questions of crisis management, materials of the $\mathrm{V}$ international scientific and practical conference, pp. 51-57, 2017.

[12] M.V. Kuntzman, V.V. Beznovskaya, A.A. Kozlova, "The value of macroeconomic proportions for studying trends in economic development" Automobile. Road. Infrastructure, vol. 4 (6). pp. 23-24, 2015.

[13] A. Movchan, "Briefly about the main thing: the Russian economy in the XXI century", The Moscow Carnegie Center. URL: http://carnegie.ru/2016/12/29/ru-pub-66503 (reference date is May 27, 2018).

[14] V.F. Yukish, "Ordinalist theory of consumer choice: some new approaches and their approbation" International scientific publication "Modern fundamental and applied research", vol. 1 (12), pp. 220-223, 2014.

[15] Execution of the federal and local budgets of the budgetary system of the Russian Federation for the year 2016/ Official website of the Ministry of Finance of the Russian Federation. URL: https://www.minfin.ru/common/upload/library/2017/09/main/isp_fed_b ud_29092017.pdf (reference date is May 25, 2018).

[16] Execution of the federal and local budgets of the budgetary system of the Russian Federation for the year 2017 (preliminary result), Official website of the Ministry of Finance of the Russian Federation. URL: ttps://www.minfin.ru/document/?id_4=122395 (reference date is May 25, 2018)

[17] Report on the results achieved to improve the business environment, the development of small and medium-sized businesses and support of individual entrepreneurial initiative. Moscow, October 11, 2017. / The official website of the Ministry of Economic Development of the Russian Federation. - URL: http://economy.gov.ru/ wps/wcm/connect/c5262b2b-2833-4be9-bcc9-

c238574c5bda/report_msp.pdf?MOD=AJPERES\&

$\mathrm{CACHEID}=\mathrm{c} 5262 \mathrm{~b} 2 \mathrm{~b}-2833-4 \mathrm{be} 9-\mathrm{bcc} 9-\mathrm{c} 238574 \mathrm{c} 5 \mathrm{bda}$ (reference date is May 27, 2018)

[18] Materials of the round table "Import Substitution: New Opportunities for the Russian Industry". URL: http://minpromtorg.gov.ru/presscentre/news/\#!8750 (reference date is May 27, 2018)

[19] Official website of the Federal State Statistics Service. URL http://www.gks.ru/wps/wcm/connect/rosstat_main/rosstat/ru/statistics/ef ficiency/\# (reference date is June 5, 2018) 
[20] The official website of the TASS news agency in Russia. http://tass.ru/obschestvo/3323225 (reference date is June 5, 2018)
[21] Migration Policy Debates / OECD, September, 2015. URL: http://www.oecd.org/els/mig/Is-this-refugee-crisis-different.pdf (reference date is January the 15th, 2017) 